\title{
EFFECT OF CLASS ATTENDANCE ON ACADEMIC PERFORMANCE
}

\author{
Ruel F. Ancheta ${ }^{1 i}$, \\ Deny Daniel' ${ }^{2}$, \\ Reshma Ahmad ${ }^{3}$ \\ ${ }^{1}$ Assistant Professor Dr., \\ Faculty of Business and Management Studies, \\ Gulf College, \\ Muscat, Sultanate of Oman \\ ${ }^{2}$ Lecturer, \\ Faculty of Business and Management Studies, \\ Gulf College, \\ Muscat, Sultanate of Oman \\ 3Programme Leader, \\ Faculty of Business and Management Studies, \\ Gulf College, \\ Muscat, Sultanate of Oman
}

\begin{abstract}
:
Student attendance is one of the issues that most teachers in Higher Education Institutions (HEIs) is facing today. Many colleges and universities have compulsory attendance policies while others have refrain from making it as such. Despite the different policies, higher education teachers believe that attendance has positive effect in academic performance. Non-attendance in class lecture is seen as one of the reasons for academic failure. This study aimed to find out the relationship between class attendance and academic performance of the L3 Omani undergraduate students in their English courses during the first semester of 2020-2021. The two English Language courses comprise 20 credit each to gauge students' English proficiency, at least IELTS 6.0, as a general entry requirement to Level 4 of the undergraduate programme. The two courses are taught separately through lectures, seminar type and practical sessions based on the module descriptors prescribed by the affiliate university. Each module is delivered in two hours and fifteen minutes per week. Thus, it is expected that each student has to attend the teaching sessions for 11 weeks with a total of 24 hours complete attendance in one semester. Result revealed that almost $71 \%$ of the L3 Omani undergraduate students had accumulated poor attendance which is below the $70 \%$ required attendance as per the attendance policy of the college. The average absence of students in the two English modules is identical with a minimum of five absences in a semester. Further, the result
\end{abstract}

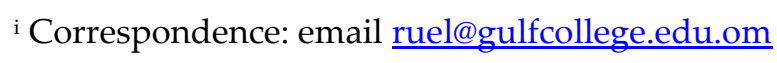


revealed that there is a significant relationship in the class attendance on the student performance in the two English modules at 0.01 level of significance. Therefore, the null hypothesis "There is no significant relationship between students' class attendance and academic performance", is rejected. The mark and absence of the students have negative inverse correlation. It means that as the absence of the student increases, the mark also decreases of at least 1 mark. It is concluded that students' class attendance is very critical in terms of learning as it affects students' achievement. To address the issue, a holistic approach to engage students both within and outside the classroom is recommended.

Keywords: attendance, academic performance, effects, learning outcomes.

\section{Introduction}

Every higher education institutions (HEIs) has its own attendance policy and practices. Some HEIs make it as compulsory with some bearing on their marks but others are not. However, even when attendance is not compulsory, many lecturers believe that it has an effect on the students' academic performance. There are a number of studies conducted on the relationship between class attendance and academic performance reaching to the conclusion that there exists a positive correlation between these two (Kirby and McElroy, 2003).

Some HEIs, attendance is required at all lectures and tutorials for the modules in which the student is registered. Punctuality also constitutes a very important part of the educational process. As per attendance policy of the college, the students have to attend classes at least $70 \%$ of the total attendance in a semester. Students who accumulated total number of absent below the required number of attendances maybe excluded from further teaching and denied access to taking examinations and refused the opportunity to submit assessment for the module, (GC Student Handbook, 2019).

In order to have an empirical answer whether or not class attendance during teaching session affects the performance of the L3 Omani students, this study was conducted to find out if class attendance has an effect on students' academic performance. The two courses of study are the English Language courses which comprise 20 credit each to gauge students' English proficiency, at least IELTS 6.0, as a general entry requirement to Level 4 undergraduate programme. These courses are taught separately through lectures, seminar type and practical sessions based on the module descriptors. Each module is delivered in two hours per week wherein each student has to attend the teaching sessions for 11 weeks for the whole semester with a total of 24 hours complete attendance.

Many studies revealed that students who attend classes on a regular basis are more likely to achieve higher grades than those students who have poor attendance. Lukkarinena et al. (2016) said that class attendance is, indeed, related to performance. However, other scholars said that physical attendance of the students in the class doesn't necessarily equal to student outcomes. Not attending class doesn't necessarily mean lower performance. Engaging students with course content and providing feedback on 
their performance will lead to an improved performance on their summative assessments.

The attendance rate of the students in the class is important because students are more likely to succeed in their academic performance when they attend classes regularly. Teachers find it difficult to make their classes interactive and build students' participation if a large number of students are frequently absent. In addition to falling behind in academics, students who are not in school on a regular basis are more likely to get low marks and believes that attendance is a baseline factor in determining student success, (Great Schools, 2017).

It is important that students have to attend and engage with the learning opportunities inside the classrooms to ensure that students feel the essence of being a student. Allen (2016) said that class attendance is a way to succeed academically. However, he believes that from time to time students may need to miss a class. Since college classes have fewer sessions compared to high school, missing one class means missing more work. Class attendance enhances class performance because through physical presence in the class, students can participate in all classroom activities. Class activities or guided learning activities given by the teacher usually help students to apply it on their final assessments. Another advantage of attending classes is that students can interact with their teacher. If there are some clarifications about the topic, students can ask questions which might be the same questions to all. So, going to the class enables students to learn from teacher and classmates. Asking questions to the teacher can provide students clear understanding of the topic which is missed out when absent from the class. Attendance to the class also increase learning. Even some of the course works are done outside the classroom, these make class sessions even more valuable. In-class time is devoted to the most challenging discussions. It's important to know what these are so that students can have a clear understanding of what is likely to show up on the final assessments.

\section{Literature Review}

Relationship between attendance and academic performance has been a debatable issue. Many scholars and researchers believed that attendance is a good predictor of academic performance while other disagree on the matter. Darling- Hammond (2000) argues that attending classes regularly is important in providing students an opportunity to achieve a desired learning outcomes.

Moreover, researchers found that when the material covered in the class was not available in the course textbook, students who attend classes benefited from interactions with the teacher and classmates and did better in the examinations. Students who attend classes also were able to take class notes, and such note taking has been shown to have positive learning benefits (Ehsan, 2013). A widely cited study of Romer (1993) on absenteeism of undergraduate students in economics reported that the average attendance rate of the students was 67 percent and showed a significant difference in the mean of GWA of students with strong attendance over those with poor attendance. He 
reported positive effects of class attendance on performance that prompted some researchers to undertake the same study to improve on attendance of students and even make it mandatory as a requirement for attending semester examinations. He even suggested that class attendance must be considered mandatory in order to increase attendance rate.

Absenteeism is one of the common problems observed by teachers today. There are many attempts that researchers have defined absenteeism. The definition depends upon the cultural setting of the students. Some experts say that students who are absent for at least two or more days are considered chronic absentees who normally gets low mark. Epstein and Sheldon (2002) said that chronic absentee students are those who missed their class of at least 20 or more school days in one academic year. However, Balfanz and Byrnes (2012) argued that chronic absentees are those students who missed their class for at least $10 \%$ or more of the total school attendance over the course of one semester or school year for whatever reason, authorized or unauthorized absences. It is believed that when the student is consistently missing his classes, he is identified as chronically absent.

The poor school attendance of the students can have an extreme effect on their academic performance. Students who are chronically absent have various reasons, however, it can positively influence on their slow academic performance (McCluskey, et al., 2004). Similarly, the poor attendance rates and the high proportion of unauthorized absences can affect the academic success and lead to poor academic performance (Zubrick, 2019).

Jaykaran, et al. (2011) conducted a research in an institute where attendance is a mandatory to students for at least $75 \%$ rate for a student to sit for a semester's final examination. In their study, there were two groups of respondents: students who had at least $75 \%$ attendance and those with less than $75 \%$ attendance. Result showed that there was statistically significant difference between the two groups for their mean mark. The mean mark of those with $75 \%$ attendance was higher than those with less than $75 \%$ attendance (unpaired t-test p,0.0067). However, a contrary result from Adegoke, et al. (2013) in their research on the impact of attendance on students' academic performance revealed a weak correlation between scores and attendance of the students. Results showed that students can still score high even they fail to attend classes.

Moreover, in a meta-analytical study on the relationship of student attendance with academic performance conducted by Crede, et al. (2010), revealed that those who have high performance are those whose attendance are very good and those students with lowest mark are those whose attendance were most likely very poor. It was also reported that the difference in marks between students with poor attendance and students with average attendance was larger than the difference between students with average attendance and students with very good attendance. 


\section{Material and Methods}

\subsection{Research Questions}

This study aimed to find out the relationship between students' class attendance and academic performance of the L3 Omani undergraduate students in their English courses during the first semester of 2020-2021. Specifically, this paper aimed to answer the following questions:

1. What is the average attendance attended by L3 Omani students in their English courses?

2. What is the average mark obtained by L3 Omani students in their English courses?

3. Is there significant relationship between students' class attendance and academic performance?

\subsubsection{Null Hypothesis}

- There is no significant relationship between students' class attendance and academic performance.

\subsection{Significance}

This study is significant to find out if the attendance in the classroom discussion has an impact on the student's performance. In spite of the attendance policy, still number of absences is high. Result of this study can provide empirical evidence and come up with a solution to address the issue to motivate students to attend classes regularly to improve their academic performance and reduce the high rate of non-submission (NS).

\subsection{Theoretical and Conceptual Framework}

\subsubsection{Theoretical Framework}

This study is based on Piaget's theory of Constructivism and the Solow Effect theory of David Romer (2001). Piaget's theory of constructivism claims that students create knowledge and form meaning based on their experiences. Through their experiences, the students create the construction of new knowledge through accommodation and assimilation. Constructivism is the theory which articulates that the students learn to create knowledge rather than just getting the information. As the students explore and interact with others, they create new information and knowledge. It is a psychologicallyoriented method to learning that stresses individual and collaborative meaning construction (Wilson, 2002). The constructivist theory is created on the idea that students are active in their learning journey because the knowledge they gained is constructed based on their experiences. While they are in the classroom, each student reflects on their own experience and integrates the new learning with their prior knowledge or schema (Kurt, 2021).

The Solow Effect theory, however, assumes that class attendance is a good predictor of students' performance. Orazem and Gunnarsson (2001) added that the Solow Effect displays relationship between attendance in school and the academic performance of the students as well as productivity. Students' presence in the class and the satisfactory 
progression are important variables on their educational achievement. The purpose of the classroom teaching is to develop human capital and transfer knowledge and skills that will support the social productivity of the students. The Solow Effect contend that the lack of family support, and social inequity increased the student's absence in the class (Thapa, 2013).

The two theories were selected in the believe that social interaction in the classroom with classmates and teacher create a construction of knowledge and additional information that can add value to the student's performance. This theory posited that while students are in the classroom, students can reflect on the new information learned and the prior knowledge he has. The Solow effect theory, however, was chosen in the assumption that attendance is a good predictor on performance.

\subsubsection{Conceptual Framework}

This study used the independent and dependent (IVDV) model. The independent variable used is the students' attendance for the two English modules for the entire semester. It is used to predict if there is a positive and negative effect on their performance. The dependent variable is the students marked for the two English modules. This is used to find out if the students' performance is affected by their class attendance. The independent variables are manipulative to find out if the pre assumed caused have direct impact to the dependent variables while the dependent variable(s) is used to measure whether the independent variable is affected by the independent variable (McLeod, 2019).

\subsection{Methodology}

\subsubsection{Research Design}

This study used descriptive quantitative method of research. Secondary data were used in analyzing the students' attendance and performance. Attendance of the students were taken from the class attendance list of the tutors. Each tutor records students' attendance every meeting and encode in the ERP system. At the end of each month, the students receive the total number of absences they accumulated. Performance of the students were taken from the internal grids kept by the module leaders. Marks recorded in the internal grids are encoded in the ERP system which is submitted to the College Registrar.

\subsubsection{Statistical Tool}

Descriptive and inferential statistics were used to analyse the data. Weighted mean (WM) and standard deviation (SD) were used to determine the average absence and performance of the students while Pearson Correlation was used to determine the significant effect of attendance on performance using Statistical Packages for Social Sciences (SPSS).

\subsubsection{Research Participants}

The participants of the study were the 155 Level 3 Omani students registered in the two English courses during the Fall 2020-2021 including the repeater (resit students). Table 1 
below shows the general information of the two English courses taken by the participants. Each module has a 20 credit delivered in 11 weeks in a semester.

\section{Results and Discussion}

This section deals with the findings, analysis and discussion of the data gathered. The following are the results and findings:

\subsection{Student Attendance}

The attendance of the students is grouped into three categories. The first category is good attendance. This category belongs to those who accumulated $85-100 \%$ total attendance in a semester. The second category is the acceptable attendance. This category belongs to those who accumulated $70-84 \%$ of total attendance in a semester. The third category is the poor attendance. Students who accumulated $69 \%$ and below total attendance in a semester fall under this category.

Table 2A shows the number and percent distribution of student's attendance in English Language Course 1 for the whole semester.

Table 2A: Number and Percent Distribution of Students Attendance by Attendance Category in English Language Course (ELC) 1

\begin{tabular}{|l|c|c|c|c|}
\hline Attendance Category & Number (N) & Percent & Mean & SD \\
\hline Good Attendance & 14 & 9.03 & 0.79 & 0.42 \\
\hline Acceptable Attendance & 27 & 17.42 & 2.70 & 0.46 \\
\hline Poor Attendance & 114 & 73.55 & 6.52 & 2.41 \\
\hline Total & $\mathbf{1 5 5}$ & $\mathbf{1 0 0}$ & $\mathbf{5 . 3 4}$ & $\mathbf{2 . 9 0}$ \\
\hline
\end{tabular}

Legend: Good Attendance (85-100\%); Acceptable Attendance (70-84\%); Poor Attendance (69\% and Below)

It is shown in the table that 73.55 percent of the students accumulated below 70 percent attendance for the whole semester. Of 155 total number of students in ELC 1 only 9.03 percent has good attendance and 17.42 percent has acceptable attendance. It can be inferred that a huge number of students are not attending their class regularly. On the average, students who accumulated absent below the $70 \%$ rule are absent for at least seven (7) days for the whole semester with a mean of 6.52. Overall, the average absent of students in ELC 1 is five (5) days with a mean of 5.34 and standard deviation of 2.90.

It shows that the average attendance attended by students in this course for the whole semester is only 6 days which doesn't fall in the $70 \%$ attendance expected from the students in attending class lecture. It implies that the attendance rate of the students in ELC 1 module is alarming as the average number of attendances fall under poor attendance category. As per the student handbook of the college, the student has to attend at least 70 percent of the total attendance in a semester in order to attend final examination, (GC Student Handbook, 2018).

Table 2B displays the number and percent distribution of student's attendance in ELC 2 for the whole semester. 
Table 2B: Number and Percent Distribution of Students Attendance

by Attendance Category in English Language Course (ELC) 2

\begin{tabular}{|l|c|c|c|c|}
\hline Attendance Category & Number (N) & Percent & Mean & SD \\
\hline Good Attendance & 17 & 10.97 & 0.94 & 0.24 \\
\hline Acceptable Attendance & 30 & 19.35 & 2.70 & 0.46 \\
\hline Poor Attendance & 108 & 69.68 & 6.76 & 2.40 \\
\hline Total & $\mathbf{1 5 5}$ & $\mathbf{1 0 0}$ & $\mathbf{5 . 3 4}$ & $\mathbf{2 . 9 9}$ \\
\hline $\begin{array}{l}\text { Legend: Good Attendance (85-100\%); Acceptable Attendance (70-84\%); Poor Attendance (69\% and } \\
\text { Below) }\end{array}$
\end{tabular}

The table shows that 69.68 percent of the students accumulated below 70 percent attendance for the whole semester in ELC 2. Of 155 total number of students only 10.97 percent has good attendance and 19.35 percent has acceptable attendance. It can be inferred that a large number of students are not attending their class religiously in this course. On the average, students who accumulated absent below the $70 \%$ rule are absent for at least seven (7) days for the whole semester with a mean of 6.76. Overall, the average absent of students in this course is five (5) days with a mean of 5.34 and standard deviation of 2.99 .

It shows that the average attendance attended by students in ELC 2 for the whole semester is only 6 days which doesn't fall in the $70 \%$ attendance expected from the students The college rule says that the student has to attend at least 70 percent of the total attendance in a semester for him to be allowed to take the final exam or submit a final coursework. It can also be implied that large number of students is affected if the policy is applied strictly.

\subsection{Student Performance}

The academic performance of the students is grouped into level of proficiency by attendance category. Table 3A shows the mean and standard deviation of students' academic performance in ELC 1 by level of proficiency.

Table 3A: Number, Mean and Standard Deviation of Students' Academic

Performance by Attendance Category and by Level of Proficiency in ELC 1

\begin{tabular}{|c|c|c|c|c|c|c|c|c|c|}
\hline \multirow{3}{*}{ Attendance Category } & \multirow{3}{*}{$\begin{array}{l}\text { Number } \\
\text { (N) }\end{array}$} & \multicolumn{6}{|c|}{ ACADEMIC PERFORMANCE } & \multirow{3}{*}{ Mean } & \multirow{3}{*}{ SD } \\
\hline & & \multirow{2}{*}{ NS } & Poor & Satisfactory & Good & Very Good & Excellent & & \\
\hline & & & $(0-39)$ & $(40-49)$ & $(50.59)$ & $(60-69)$ & $(70-79)$ & & \\
\hline Good Attendance & 14 & 0 & 1 & 8 & 2 & 0 & 3 & 50 & 13.39 \\
\hline Acceptable Attendance & 27 & 0 & 1 & 13 & 11 & 2 & 0 & 49 & 6.36 \\
\hline Poor Attendance & 114 & 26 & 9 & 59 & 17 & 3 & 0 & 35 & 19.86 \\
\hline TOTAL & 155 & 26 & 11 & 80 & 30 & 5 & 3 & 38.82 & 18.67 \\
\hline
\end{tabular}

The table shows that the average mark of students who accumulated good attendance is 50 mark with standard deviation of 13.39 and 49 mark for those who accumulated 
acceptable attendance with standard deviation of 6.36 . On the other hand, those who accumulated poor attendance, has an average mark of at least 35 mark, which is a failing mark, with a standard deviation of 19.86. Overall, the average mark of the students obtained in ELC 1 is 38 with a standard deviation of 18.67 which fall under poor level of proficiency.

Table 3B displays the mean and standard deviation of students' academic performance in ELC 2 by level of proficiency.

Table 3B: Number, Mean and Standard Deviation of Students' Academic

Performance by Attendance Category and by Level of Proficiency in ELC 2 (N=155)

\begin{tabular}{|c|c|c|c|c|c|c|c|c|c|}
\hline \multirow{3}{*}{ Attendance Category } & \multirow{3}{*}{\begin{tabular}{|c} 
Number \\
$(\mathrm{N})$ \\
\end{tabular}} & \multicolumn{6}{|c|}{ ACADEMIC PERFORMANCE } & \multirow{3}{*}{ Mean } & \multirow{3}{*}{ SD } \\
\hline & & NS & Poor & Satisfactory & Good & Very Good & Excellent & & \\
\hline & & & $(0-39)$ & $(40-49)$ & $(\mathbf{5 0 - 5 9 )}$ & $(60-69)$ & $(70-79)$ & & \\
\hline Good Attendance & 17 & 1 & 0 & 6 & 9 & 1 & 0 & 49 & 13.83 \\
\hline Acceptable Attendance & 30 & 0 & 3 & 13 & 14 & 0 & 0 & 48 & 5.98 \\
\hline Poor Attendance & 108 & 24 & 4 & 46 & 30 & 4 & 0 & 37 & 20.87 \\
\hline TOTAL & 155 & 25 & 7 & 65 & 53 & 5 & 0 & 40.57 & 18.86 \\
\hline
\end{tabular}

It can be shown from the table that the average mark of students who accumulated good attendance is 49 mark with standard deviation of 13.83 and 48 mark for those who accumulated acceptable attendance with standard deviation of 5.98. On the other hand, those who accumulated poor attendance, has an average mark of at least 37 mark, which is a failing mark, with a standard deviation of 20.87. Overall, the average mark of the students obtained in ELC 2 is 41 with a standard deviation of 18.86 which fall under satisfactory level of proficiency.

Table 4: Summary of Students Attendance and Performance by Course

\begin{tabular}{|l|c|c|c|c|c|}
\hline Course Name & \multirow{2}{*}{$\begin{array}{c}\text { Number } \\
\text { (N) }\end{array}$} & \multicolumn{2}{|c|}{ Attendance } & \multicolumn{2}{c|}{ Academic Performance } \\
\cline { 3 - 6 } & & Mean & SD & Mean & SD \\
\hline ELC 1 & 155 & 5.33 & 2.90 & 38.81 & 18.67 \\
\hline ELC 2 & 155 & 5.34 & 2.99 & 40.57 & 18.86 \\
\hline Total & $\mathbf{3 1 0}$ & $\mathbf{1 0 . 6 7}$ & $\mathbf{5 . 8 9}$ & $\mathbf{7 9 . 3 8}$ & $\mathbf{3 7 . 5 3}$ \\
\hline
\end{tabular}

In summary, it can be shown in tables $2 a$ and $2 b$ that the average number of absences of students in the two courses is identical with a minimum number of five (5) absences with a mean of 5.34 respectively in each module with an overall mean of 10.67 and a standard deviation of 5.89. It can be posited that if the student is absent in ELC 1, the student is also absent in ELC 2. At the end of each month, each student receives a letter indicating the total number of absences accumulated. However, in spite of the report and warnings received on the students' accumulated number of absences, still the rate of absences in the two modules is high.

When it comes to the students' performance, the average mark of the students differs from each other with a mean of 38.81 for ELC 1 and 40.57 for ELC 2. The average 
mark of the students in ELC 1 is 38 while in ELC 2 is 40 . It can be inferred that students' mark in ELC 2 is higher of at least 1.75 compared to ELC 1. Since attendance rate of the students is low, the question is whether attendance policy can be a mandatory or not. Romer (1993), expressed his concern on the rampant absenteeism among students. He wondered whether mandatory attendance is worth trying and if it is meritorious in terms of pedagogical point of view. Mcfarlane (2013) said that students might attend the class because of the mandatory attendance policy without displaying sense of engagement in the classroom.

\subsection{Effect of Class Attendance on Academic Performance}

To predict the extent of the effect of class attendance on academic performance of students in English courses, the researchers tested the null hypothesis "There is no significant relationship between students' class attendance and academic performance.".

Table 5 shows the correlations of student's absences and academic performance. Result of Pearson Correlation shows that there is statistically significant positive correlation between attendance and academic performance of the students in the two English courses.

Table 5: Correlations of Students Attendance and Academic Performance

\begin{tabular}{|l|l|c|c|}
\hline \multirow{2}{*}{ Mark } & Pearson Correlation & Mark & Absence \\
\cline { 2 - 4 } & Sig. (2-tailed) & 1 & $-.516^{* *}$ \\
\cline { 2 - 4 } & $\mathrm{N}$ & & .000 \\
\hline \multirow{3}{*}{ Absence } & Pearson Correlation & 310 & 310 \\
\cline { 2 - 4 } & Sig. (2-tailed) & $-.516^{* *}$ & 1 \\
\cline { 2 - 4 } & $\mathrm{N}$ & .000 & 310 \\
\hline
\end{tabular}

**. Correlation is significant at the 0.01 level (2-tailed).

Table 5 revealed that there is a significant relationship in the class attendance on the student performance in the two English courses at 0.01 level of significance. Thus, the null hypothesis is rejected. It can also be noted that the mark and absence of the students have negative inverse correlation of -.516. It means that as the absence of the student increases, the mark also decreases of at least 1 mark. The result of the present study is similar to the result of AbuRuz (2015) on his investigation about the effect of absenteeism rate on the academic achievement of graduate and undergraduate nursing students which showed negative correlation between absenteeism and academic achievement.

Olufunmilayo (2017) on his study about the class attendance and academic performance of second year university students in an organic chemistry course also revealed that class attendance has significant correlation on the students' performance in examination scores. It can be argued that class attendance is an important contributor to a student's academic achievement - all school days matter. The correlation between absence and achievement is consistently negative and declines in achievement are evident with any level of absence. Although some absences are authorized, a smaller amounts of absence were associated with only minimal declines in performance. That 
means all absences matter, and the effect of absence increases with the number of absences (Hancock et al., 2013). Many studies shows that students who are attending classes regularly have scored better and gained more knowledge from attending classes and can make good mark. Results of the present study clearly support this concept.

To further show the empirical evidence on the effect of students' attendance on their academic performance, a multiple regression is shown in Table 6.

Table 6: Correlation of Students Absence and Performance Using Multiple Regression

\begin{tabular}{|c|c|c|c|c|c|c|}
\hline \multicolumn{7}{|c|}{ Coefficients ${ }^{a}$} \\
\hline \multirow{2}{*}{\multicolumn{2}{|c|}{ Model }} & \multicolumn{2}{|c|}{$\begin{array}{l}\text { Unstandardized } \\
\text { Coefficients }\end{array}$} & \multirow{3}{*}{$\begin{array}{c}\begin{array}{c}\text { Standardized } \\
\text { Coefficients }\end{array} \\
\text { Beta } \\
\end{array}$} & \multirow{2}{*}{$\mathbf{t}$} & \multirow{2}{*}{ Sig. } \\
\hline & & B & Std. Error & & & \\
\hline \multirow[t]{5}{*}{1} & (Constant) & 65.373 & 5.084 & & 12.858 & .000 \\
\hline & Module & 1.749 & 1.793 & .047 & .975 & .330 \\
\hline & Gender & .603 & 1.836 & .016 & .328 & .743 \\
\hline & Status & -11.265 & 2.973 & -.183 & -3.789 & .000 \\
\hline & Absence & $\begin{array}{l}-3.132 \\
\end{array}$ & .307 & -.492 & -10.195 & .000 \\
\hline
\end{tabular}

Dependent variable: Mark

Absence and status are correlated (statistically significant relations) at 0.004 level of significance.

As shown in the table, students' attendance and their status are good predictors of academic performance. The number of absences significantly affects the marks of the students with .000 level of significance. This means that as the absence of the students increases, there is a decrease of 10.195 in their marks. Also, the student status is a good predictor of academic performance. Regular and resit students have significant difference on their marks with .000 level of significance. It means that the marks of the resit students is decreased by 3.789 in every one absence. On the other hand, other variables like: module and gender are not good predictors of mark. As shown in the table the marks of the students in ELC 2 increase by 0.975 with .330 level of significance. Gender differences in ELC 1 and ELC 2 are crossed out. It means that the marks of female students increase by 0.328 with .743 level of significance.

It can be inferred from the result that class attendance has an effect on the students' academic performance. It clearly shows that attendance is a major factor affecting students' performance which is similar to the result found by Ricardo (2011) when he investigated "Should Students be allowed to miss?" which says that as absenteeism rates increases the academic achievement decreases. The same results were found in this study. According to Hancock, et al. (2017) "Every day counts and there is no 'safe' threshold for absences". Failing marks are evident with any level of absence. The greater number of absences are normally associated with larger drops in students' academic performance achievement (Gottfried, 2014; Hancock et al., 2013). The effects of not attending classes on academic performance are accumulative and can affect both academic achievement and attendance in future years of schooling (Hancock et al., 2013; Zubrick, 2014). In similar study conducted by Chilwant K. S.(2013) highlights that while student 
absenteeism may contribute to low achievement, the reverse is also possibly true, where low achievers are more likely to absent themselves than higher achievers.

\section{Recommendations}

Addressing attendance requires a holistic approach to engage students within and outside the classroom. Since attendance of the students is an alarming issue, attendance improvement initiatives need to be done to improve students' attendance. The researchers are guided with the theory of action model to come up with course of actions. This model outlines: a) monitoring of student absences, b) support system mechanism, c) evaluation of available resources, and d) extending support services to families. Thus, the researchers recommended that tutors should record daily attendance of the students to monitor regular absentees. Warning letter must be sent regularly to students who accumulated poor attendance. Students who accumulated below the $70 \%$ required attendance should be informed prior to the Final Examination for them to be aware of any consequences. Students identified as regular absentees need to be contacted by the tutor and the Academic Advisor to find out the reasons of not attending classes. Academic Advisors need to facilitate meetings with their advisees particularly those students at risk due to their poor attendance. Tutors need to prepare independent learning activities that would attract students to attend classes. Tutors should employ teaching strategies that would enhance the attendance rate of students in their classes. Encourage students to utilize the college's learning management system like: MOODLE, ERP, and other mode of learning modality. Encourage students to utilize their college email, MS Teams and other applications to reach their tutors and academic advisor. Implement attendance policy that brings students into class and should be put in place to ensure the attendance of students in class will improve and their over-all performance. Students with good attendance should be rewarded. Class tutors should inform students the benefits of attending the classes. A survey questionnaire should be sent to students find out the reasons for being absent. Results of the survey needs to be analysed to come up with strategies to improve student attendance. Various platforms such as student council meetings, programme review committee meetings, student engagement meeting need to be facilitated to ensure students' awareness on the importance of attending classes. Parents or guardians of students with poor attendance need to be contacted to find out the reasons why students are being absent from classes and provide regular counselling to regular absentees.

\section{Conclusion}

Based on the results and findings, the current study provides empirical evidence on the effect of class attendance on academic performance of the students. It is noted that $70 \%$ of the L3 Omani students accumulated poor attendance which is $69 \%$ and below. The average absence of students in the two English courses is identical with a minimum of five absences in a semester. Further, the result displayed that there is a significant 
relationship in the class attendance on the students' performance in the two English courses at 0.01 level of significance. Thus, the null hypothesis is rejected. It can also be noted that the mark and absence of the students have negative inverse correlation. It means that as the absence of the student increases, the mark also decreases of at least 1 mark. Therefore, students' class attendance is very critical in terms of learning as it affects students' achievement.

\section{Acknowledgements}

The authors wish to acknowledge those who, in one way or another, contributed a lot in the finalization of this study. The authors are indebted to the Community of Practice (CoP) team headed by Dr. Ravindra for their valuable suggestions and comments during the presentation of results and findings for feedback.

\section{Conflict of Interest Statement}

The authors declare no conflicts of interests.

\section{About the Authors}

Dr. Ruel F. Ancheta is currently an Assistant Professor in Gulf College with more than 2 decades of teaching experience at graduate and undergraduate levels. Coupled with his teaching, he has massed industry experience in the field of HR, training, and development. He is a motivated lecturer who strives to make each student feel heard and cared for. He is dedicated to his profession and committed to the development of his students. His field of interests are English Language Teaching, Educational Management and Leadership, and Human Resource Management and Development. He is currently a member of the Research Council- Oman (TRC). He has written and published various researches in the field of education and English Language Teaching. The recent study he conducted and published is the "New Normal in Education: A Challenge to the Private Basic Education Institutions in the Philippines" published by the International Journal of Education and Development Studies.

Ms. Deny Daniel is an accomplished lecturer, with more than 20 years of teaching experience in leading academic institutions in India and the Sultanate of Oman. She is a postgraduate in English Language and Literature. She has been teaching English as a foreign language to students in non-English-speaking countries. Her field of interests are Educational Psychology, Multicultural Education, Second Language Acquisition, Teaching Technologies, and New Media, Online Learning. She has co-authored and published paper on "Challenges Encountered by EFL Tutors of Academic Study Skills Module: A Pedagogical Point of View" published by the International Journal of Social Science and Technology.

Mrs. Reshma Ahmad is one of the senior lecturers in Gulf College, who also serves as a Programme Leader within the Faculty. Throughout her career in Gulf College since 2004, she has been involved in teaching, learning and assessment development and administration process for Staffordshire University and Cardiff Metropolitan University programmes. She has over 26 years of academic and industry-linked experience in the 
field of teaching and managing academic affairs. She closely works with the industry to ensure the syllabus being taught in the college is on par with the needs of the job market as well as international higher education standards. Her expertise lies in developing teaching and learning materials as well as in developing formative and summative assessments. Her field of interest is on educational management, teaching philosophy, and corporate governance.

\section{References}

AbuRuz, M. (2015). Does Excessive Absence From Class Lead to Lower Levels of Academic Achievement?, European Scientific Journal, Vol 11, No. 7

Adegoke, B. O., Salako, R. J., \& Ayind, L. A. (2013). Impact of attendance on students' performance in ICT related courses: Faculty of engineering, Osun State Polytechnic, Iree. Journal of Education and Practice, 4(16), 95-98.

Allen, W. (2016). Class Attendance, Available [Online] at www.courses.lumen.com, Date Accessed, 16 March 2021.

Attendance Initiatives, Theory of Action, Buffalo Public Schools (NY), Available online at www.buffaloschools.org, Date Accessed 10 March 2021.

Adegoke, B. O., Salako, R. J., \& Ayind, L. A. (2013). Impact of attendance on students' performance in ICT related courses: Faculty of engineering, Osun State Polytechnic, Iree. Journal of Education and Practice, 4(16), 95-98.

Arulampalam, W., Naylor, R. A., \& Smith, J. (2012). Am I missing something? The effects of absence from class on student performance, Economics of Education Review, 31, 363 375. http://dx.doi.org/10.1016/j.econedurev.2011.12.002.

Andrietti V. (2014). Does lecture attendance affect academic performance? Panel data evidence for introductory macroeconomics. International Review of Economics Education 15: 1-16.

Andrietti V. and Velasco C. (2015). Lecture attendance, study time, and academic Performance: A panel data study, The Journal of Economic Education 46(3): 239-259.

Balfanz, R., and Byrnes, V. (2012). The Importance of Being in School: A Report on Absenteeism in the Nation's Public Schools. Baltimore, MD: Johns Hopkins University Center for Social Organization of Schools. Retrieved August 19, 2016, from http://new.every1graduates.org/the-importance-of-being-in-school/

Chilwant K. S. (2013). Effect of Class Attendance on Performance in Examination in Second Year Medical Students. Journal of Research \&Method in Education, 3(3), 31-33.

Crede, M., Roch, S. G., \& Kieszczynka, U. M. (2010). Class attendance in college: A meta analytic view of the relationship of class attendance with grades and student characteristics. American Educational Research Association, 80, 272-295. http://dx.doi.org/10.3102/0034654310362998

Darling-Hammond, L. (2000). Teacher Quality and Student Achievement: A Review of State Policy Evidence, Education Policy Archives, 8 (1) pp 154. 
Epstein, J. L., and Sheldon, S. B. (2002). Present and accounted for: Improving student attendance through family and community involvement. The Journal of Educational Research, 95(5): 308-317.

Ehsan Latif, S. M. (2013). Class Attendance and Academic Performance: A Panel Data Analysis. The Economic Society of Australia, 32(4), 470-476.

Gonski, D., Arcus, T., Boston, K., Gould, V., Johnson, W., O’Brien, L., ... Roberts, M. (2018). Through Growth to Achievement: The Report of The Review to Achieve Educational Excellence in Australian Schools. Canberra: Commonwealth of Australia.

Great Schools (2017). Why Attendance Matters, Available [Online] at www.greatschools.org, Date Accessed, 17 March 2021.

Hancock, K. J., et al. (2017). Associations between school absence and academic achievement: Do socioeconomics matter? British Educational Research Journal, 43(3), 415-440. https://doi.org/10.1002/berj.3267.

Jaykaran, Yadaav, P., Chavda, N., Kantharia, N. D. (2011). Factors associated with performance of second year student in pharmacology examinations. Journal of pharmacology and pharmacotherapeutics, 2(2),123-125.

Kirby A. and McElroy B. (2003) "The Effect of Attendance on Grade for First Year Economics Students in University College Cork", The Economic and Social Review, 34(3), pp. 311-326.

Kurt, S. "Constructivist Learning Theory," in Educational Technology, February 21, 2021. Retrieved from https://educationaltechnology.net/constructivist-learning-theory.

Lukkarinena, et al. (2016). Relationship between Class Attendance and Student Performance', Available [Online] www.sciencedirect.com, Date Accessed 09 March 2021.

Macfarlane B. (2013). The surveillance of learning: A critical analysis of university attendance policies. Higher Education Quarterly 67(4), pp.358-373.

McLeod, S. (2019). What are Independent and Dependent Variables, Available [Online] at www.simplypsychology.org, Date Accessed, 14 June 2021

McCluskey, C., Bynum, T. S., and Patchin, J. W. (2004). Reducing chronic absenteeism: An assessment of an early truancy initiative. Crime and Delinquency, 50(2): 214234

Maynard, B. R., McCrea, K. T., Pigott, T. D., and Kelly, M. S. (2013). Indicated truancy interventions for chronic truant students: A Campbell systematic review. Research on Social Work Practice, 23(1): 5-21.

New Student Induction Pack (2019). Primary Rules and Regulations of the College on Attendance, Gulf College, AY 2018-2019.

Olufunmilayo P. (2017). Class Attendance and Academic Performance of Second Year University Students in an Organic Chemistry Course, African Journal of Chemical Education, Vol.8 No.7

Ricardo D. Paredes (2011). Should Students Be Allowed to Miss? The Journal of Educational Research, 104 (3), 194-201.

Romer, D. (1993). Do students go to class? Should they? The Journal of Economic Perspectives, 7, 167-174. http://dx.doi.org/10.1257/jep.7.3.167. 
Thapa, S. B. (2013). Relationship between education and poverty in Nepal, Economic Journal of Development Issues, 15 \& 16 (1):148-161.

The Smith Family (2018). Attendance lifts achievement: Building the evidence base to improve student outcomes, Research Report. The Smith Family.

Wilson, B. G. (2002). Trends and futures of education, Implications for distance education. Quarterly Review of Distance Education, 3(1), 103.

Zubrick, S. R. (2019). School Attendance: Equities and Inequities in growth trajectories of academic performance. University of West Australia and Telethon Kids Institute. https://research.acer.edu.au/research conference/RC2014/4august/7. 
Ruel F. Ancheta, Deny Daniel, Reshma Ahmad

Creative Commons licensing terms

Author(s) will retain the copyright of their published articles agreeing that a Creative Commons Attribution 4.0 International License (CC BY 4.0) terms will be applied to their work. Under the terms of this license, no permission is required from the author(s) or publisher for members of the community to copy, distribute, transmit or adapt the article content, providing a proper, prominent and unambiguous attribution to the authors in a manner that makes clear that the materials are being reused under permission of a Creative Commons License. Views, opinions and conclusions expressed in this research article are views, opinions and conclusions of the author(s). Open Access Publishing Group and European Journal of Education Studies shall not be responsible or answerable for any loss, damage or liability caused in relation to/arising out of conflicts of interest, copyright violations and inappropriate or inaccurate use of any kind content related or integrated into the research work. All the published works are meeting the Open Access Publishing requirements and can be freely accessed, shared, modified, distributed and used in educational, commercial and non-commercial purposes under a Creative Commons Attribution 4.0 International License (CC BY 4.0). 